Journal of Money and Economy

Vol. 15, No. 4, Fall 2020

pp. 381-402

DOI: $10.29252 /$ jme.15.4.381

Original Research Article

\title{
Accruals Quality and Bankruptcy in Shirata Model (Case Study: Tehran Stock Exchange)
}

\begin{tabular}{ll}
\hline Oveis Bagheri" $^{*}$ & Mona Ranjbaran Jalili $^{\dagger}$ \\
\hline Received: 30 Sep 2020 & Approved: 5 May 2021 \\
\hline
\end{tabular}

In this research, the relationship between accruals quality and bankruptcy of companies has been studied. According to Dechow et al.'s (1995) model, the quality of accruals was measured, and according to the Shirata model (1998), bankruptcy was examined. Operations were considered as the control variables. The research hypothesis was tested using a multivariate regression model and a combined data method. The study's statistical sample consists of 197 companies listed on the Tehran Stock Exchange from 2011 to 2019. The results showed a significant and negative relationship between the quality of accruals and bankruptcy of the companies. It means that in bankruptcy, the use of earnings management through optional accruals reduces the quality of accruals. The results indicate that size, return on assets, and audit quality all significantly impact the quality of accruals. Besides, the leverage, life, and operating cash flow have a significant and negative effect on accruals' quality. However, the ratio of market value to book value does not significantly affect the quality of accruals.

Keywords: Quality of Accruals, Bankruptcy, Shirata Model, Tehran Stock Exchange, Profit Management.

JEL Classification: A11, G33, H83

\section{Introduction}

Financial reporting aims to provide information about the financial status, financial performance, and financial flexibility of different users to help them make the right decisions. Financial reports should always provide reliable information to help users make decisions. The financial statement should contain relevant, reliable, comparable, and understandable information. In recent years, the accounting scandals that occurred in the international financial community have led to an increase in the cost of financial reporting

\footnotetext{
* Faculty of Management, University of Tehran, Tehran, Iran; ov.management.m.a@gmail.com (Corresponding Author)

$\dagger$ Department of Accounting, Fontbonne University, St. Louis, MO., USA;

Ranjbaran_mona@yahoo.com
} 
quality. Most researches done on the quality of financial reporting is based on agency theory. Due to the separation of ownership from the management in stock corporates and the conflict between the owners' interests of and the executives ' interests and the flexibility of accounting standards, the reporter unit management likely mislead the users by applying the financial reporting to maximize its interests. According to the representation theory (Chriss \& Ginzburg, 2010), executives as the representatives of shareholders may act in a manner or make decisions that do not necessarily maximize the shareholders' wealth. According to this theory, there should be sufficient control or oversight mechanisms to protect the shareholders against interest conflicts.

The issue "quality of financial reporting of the presented information has been considered as a practical approach. Transparent and high-quality information flow reduces information asymmetry. Corporates can reduce information asymmetry by improving the quality of financial reporting. In this paper, we study this concept for some companies consisting of 197 companies listed on the Tehran Stock Exchange from 2011 to 2019. Based on Jouzbarkand et al. (2013), the study on the bankruptcy prediction model by Ohlson and Shirata models in the Tehran Stock Exchange. In the next section, we will explain their research thoroughly. Based on the following sections' journal framework, there are a literature review, a methodology and a research model, and a conclusion and discussion.

\section{Literature Review}

Many studies are related to accruals quality and bankruptcy. Aldahray and et al. (2020) have studied the impact of the regulatory environment on accruals manipulation of bankrupt firms. This study aims twofold: first, to determine whether bankrupt firms manipulate signed accruals upwards compared with active firms with similar performance, and second, whether the regulatory environment influences pre-bankruptcy manipulation. The study results suggest that managers in bankrupt AIM firms have greater incentive and ability to manipulate accruals upwards than managers in Main Market firms. Finally, the negative accruals manipulation subsample shows that AIM bankrupt firms manipulate accruals downwards more than Main Market bankrupt firms. Financial reporting aims to provide information that helps investors, creditors, and other users make economic decisions. One of the key figures is the profit that consists of cash and accruals. The executives largely control the accrual of profit. Executives can manage the profit to better show off the corporate's performance and increase the ability to predict the future 
profits in accruals. On the one hand, accruals allow the executives to calculate the profits to represent the corporate's true value.

On the other hand, these items allow executives to abusive the flexibility of accepted accounting methods and principles and distort the information content of profit. Prior research suggests that accruals' quality may be compromised where the magnitude of accruals is abnormally high due to the presence of errors in the accruals-estimation process (Dechow and Dichev, 2002; Richardson, 2003). A consequence of the study by Al-attar and et al. (2008) is that abnormal accruals may not map into realized future cash flows to the extent that it would normally be expected of accruals data. Indeed, the association may be insignificant if abnormal accruals consist primarily of estimation noise. This study investigates whether abnormal accruals for UK firms provide incremental insight into future cash flows. Also, we know that there has been growing concern worldwide regarding audit quality in all countries, especially in Japan after the Kanebo and Olympus accounting scandals. Based on Semba and et al. (2019), this could be a critical issue. The purpose of their paper is to examine the Japanese audit market from 2001 to 2011 to determine whether audit quality differs between Big N and Non-Big $\mathrm{N}$ audit firms and whether this difference if existed, changed during 2007 when the number of big audit firms declined from four to three and the requirements of audit quality became more rigorous.

Corporates are associated with three broad categories of information users: society, fund providers, and executives. In the case of the first two groups, the society, and fund providers, the profit manipulation is conducted to minimize the political costs and capital costs and the corporate benefits from the transfer of wealth, but in the case of the third group, the executives manipulate profits for their benefit and maximize their remuneration. Based on the representation theory, management's motivation is to manipulate profit to achieve its goals, which does not necessarily coincide with the shareholders' goals, but in most of the vast majority of cases conflict with those goals. (Stolowy \& Berton, 2004). Of course, the management motivation increases in years when the corporate financial situation is undesirable, and signs of a move towards a financial crisis for the manager emerge from hiding the corporate's poor performance. That is why the reported profit value is uncertain. The empirical evidence suggests that the manipulation of accruals and actual activities have been occurred more in the corporates threatened with bankruptcy and financial distress (Garcia Lara, Garcia Osma \& Neophytou, 2009). In the corporate financial crisis, the corporate executives are willing to transfer useful information and good news to the capital market to avoid the corporate value 
(Biddle, Ma \& Song, 2020; Vichitsarawong \& Eng, 2010). Besides, based on Jouzbarkand et al. (2013), the increase of trading exchange capacity in the Iranian trading stock market clears the use of models that can predict Iranian companies' financial position. Using the financial ratios is a useful method to analyze the financial reports, the prediction of financial distress, and bankruptcy. In their research, they made two models for the prediction of bankruptcy regarding the Iranian economic situation. Also, they studied the Ohlson and Shirata models using the logistic regression method. For this purpose, the researchers have examined and compared the ability of "Ohlson and Shirata" models. For classifying and ranking companies, they used "Article 141" of business law to determine the bankrupt companies, as well as simple Q-Tobin to specify the solvent companies.

Moreover, they used the "Enter Logistic" statistical method to test the first and second hypotheses. The results show that created models can predict bankruptcy. Also, the recent world financial crisis has increased the number of bankruptcies in numerous countries. It has resulted in a new research area that responds to the need to predict this phenomenon at the level of individual countries and a global level, offering explanations of the common characteristics shared by the affected companies. Nevertheless, few studies focus on the prediction of bankruptcies globally. To compensate for this lack of empirical literature, Alamminos et al. (2018) worked on this area. Their study has used a methodological framework of logistic regression to construct predictive bankruptcy models for Asia, Europe, and America, and other global models for the whole world. The objective is to construct a global model with a high capacity for predicting bankruptcy in any region of the world. The results obtained have allowed them to confirm the global model's superiority compared to regional models over periods of up to three years before bankruptcy (Alaminos et al., 2018). In another study, some researchers worked on two models for the Tehran Stock Exchange. Concerning recent bankruptcies in large international companies and the high risk of the Tehran Stock Exchange, assessing the companies for their financial power is necessary.

One of the instruments for assessing financial power is financial ratios. Their research aims to obtain new models based on Zmijewski and Shirata models in the Tehran Stock Exchange condition. For obtaining these models, hypothesize are divided into two groups. The first group is about the power of classifying corporations into bankrupt and non-bankrupt. These hypotheses confirm the power of correct classifying. The second group is about the difference between the importance of financial ratios as an independent 
variable. These hypotheses confirm the difference between the importance of independent variables in predicting corporate failures. Also, the Friedman test indicates there is no preference between hypotheses, and they have the same efficiency.

The bankrupt corporates' executives may manipulate their financial information to hide or postpone the bankruptcy status (Healy \&Whalen, 1999). Therefore, the executives of bankrupt corporates have more incentives to manage the accruals. On the other hand, non-broken corporates are marked by an increase in receivable accounts, inventories, property, machinery and equipment, sales, networking capital, and optional accruals in financial statements. Therefore, financial distress and financial bankruptcy can be essential in the information content of accounting data. Considering the high importance of determining the financial distress and bankruptcy of corporates in making economic decisions and allocating the optimal resources, as well as the issue of financial reporting quality in previous years, this research investigate the relationship between the accruals quality and bankruptcy in listed corporates in the Tehran Stock Exchange. This issue has great importance for the researchers, auditors, and regulatory authorities. The expected executive applications of the research should not be overlooked. For example, in the case of a decrease in profit quality, the relevant authorities can investigate the cause and improve the quality of profit by formulating the regulations and providing other necessary measures to protect this information's users. In the last years, on the one hand, the fight against economic corruption has been seriously addressed by the community and the government. On the other hand, the size and number of public corporates and users of accounting information are increasing, and the quality of profit and the quality of accruals are expected to be important. It is hoped that the risk and role of management in corporate fraud followed by the profit management be clarified for both users and auditors, and the structures affecting the quality of accruals also be identified. The results of this study can be used by different groups, including the Tehran Stock Exchange, directors and board of directors of corporates, shareholders and investors, banks and creditors, audit organization and other auditors, financial analysts, stockbrokers, stock market participants, researchers, and financial sector enthusiasts.

\section{Data Collection and Methodology}

The present research describes past events and the study of relationships. As a result, the research is a descriptive type based on the method and manner in which the relations are investigated through a multivariate regression model 
based on the corporate-year observations. The data are retrospective and postevent. The collection of information is intended to express theoretical literature and the literature review of the research by the library method, which includes the use of the materials contained in the dissertations and foreign and domestic articles. The initial required data related to the research variables were collected based on the information in the annual financial statements, information banks belonging to the Stock Exchange, the board of directors' report, and the auditor's report. Excel software was used to collect and organize the data, and E-views software for data analysis. In 2003, Dr. Shirata introduced the SAF2002 bankruptcy prediction model. The acronym SAF stands for Simple Analysis of Failure. The SAF2002 model was developed by analyzing 1,436 bankrupt companies' financial data and 3,434 non-bankrupt companies extracted by a systematic sampling method from 107,034 companies. The model's variables were selected by using a Classification and Regression Tree (CART) type of decision tree learning approach to analyze the financial data of Japanese companies that entered bankruptcy between 1992 and 2001. The four variables of the model that the CART approach identified are:

$\left(x_{1}\right)$ Retained Earnings to Total Liabilities and Owners' Equity,

$\left(x_{2}\right)$ Net Income before Tax to Total Liabilities and Owners' Equity,

$\left(x_{3}\right)$ Inventory Turnover Period, and

$\left(x_{4}\right)$ Interest Expenses to Sales.

Based on a linear model, which exhibited the most stable and discriminant results, the model's SAF value for each firm is based on the following equation:

$S A F=0.7077+0.0104 x_{1}+0.0268 x_{2}+0.0661 x_{3}+0.0237 x_{4}$

A SAF value of 0.7 or below quickly raises a firm's bankruptcy risk.

\subsection{Population and Research Sample}

The corporates listed in the Tehran Stock Exchange for nine years (2010 2019) are considered the research's statistical population. The corporates are screened using the following method, and the other corporates have been removed:

- During these nine years (2010 -2019), Some companies have entered or left this market

- Companies such as banks, insurers, investments, and financial intermediaries. 
- During the study period, they change their financial report time.

The research group included 197 corporates listed in the Tehran Stock Exchange during nine years, and the research data were reviewed during these nine years "2011-2019" (Since the data for the year 2010 are applied as the basis for calculating the variables that must be measured according to the changes). Accordingly, the number of analyzed data includes 1182 corporateyear observations.

\subsubsection{Research Hypothesis}

This research determines how the risk of corporate confrontation with the state of bankruptcy affects accruals and quality. To answer the research question, the research hypothesis was developed as follows:

H1 There is a significant relationship between the quality of accrual and bankruptcy of corporates.

\subsubsection{Research Model}

A multivariate regression model has been used to test the hypothesis of the research. This model is presented with a description of how its variables (Alexopoulos, 2010) are measured in Table 1.

$$
\begin{aligned}
& \operatorname{ACCRUAL}_{i, t}=\alpha+\beta_{1} B A N K R U P T_{i, t}+\beta_{2} \operatorname{SIZE}_{i, t}+\beta_{3} L E V_{i, t}+ \\
& \beta_{4} R O A_{i, t}+\beta_{5} A G E_{i, t}+\beta_{6} A U D_{i, t}+\beta_{7} M_{K T B K_{i, t}}+\beta_{8} O C F_{i, t}+\varepsilon_{i, t}
\end{aligned}
$$

In which:

$\boldsymbol{A C C R U A L}_{i, t}$ : Represents the quality of accruals.

$B A N K R U P T_{i, t}$ : Represents the bankruptcy.

$S I Z E_{i, t}:$ Represents obtained from the logarithm of the total assets.

$L E V_{i, t}$ : Represents the ratio of total liabilities to the total assets.

$R O A_{i, t}$ Represents the ratio of net profit to the total assets.

$A G E_{i, t}$ : Represents the natural logarithm of the spent time since the corporate was founded.

$A U D_{i, t}$ : Represents the quality of the auditing. If the corporate auditor is the auditing organization, the number one and otherwise number zero would be set.

$M K T B K_{i, t}$ : The ratio of the stock market value to the total equity.

$O C F_{i, t}$ : The ratio of cash flow from operating activities to the total assets.

The model and its details are as follows: 
$\frac{T A C C_{i, t}}{A_{i, t-1}}=\alpha+\beta_{1} \frac{\left(\Delta R E V_{i, t}-\Delta R E C_{i, t}\right)}{A_{i, t-1}}+\beta_{2} \frac{P P E_{i, t}}{A_{i, t-1}}+\varepsilon_{i, t}$

$T A C C_{i, t}$ : Total accruals; Difference between the operating profit and operating cash flow

$\triangle R E V_{i, t}$ : Change in incomes; Difference between the incomes for two consecutive periods

$\triangle R E C_{i, t}$ : Change in incomings; Difference between incomings for two consecutive periods

$P P E_{i, t}$ : Property, machinery, and equipment

$A_{i, t-1}$ : Total assets of the previous period

$\varepsilon_{i, t}$ : The model error that represents the optional accruals and profit management index. The lower the number of accruals, the lower the profit management through the accruals, but the accruals' quality is greater.

At first, based on the Jones (1991) modified error proposed by Dechow et al. (1995), the optional accruals were obtained and used as the profit management. Since the accrual quality is a concept reverse of the profit management through the accruals, the quality of accruals was calculated through the absolute value of the model error values.

According to the Shirata model (1998), the probability of bankruptcy was assessed. Shirata used multiple differentiation analysis methods for the model. The model and its detailed description are as follows:

$Z_{i, t}=0.7416+0.014 X_{1}-0.003 X_{2}-0.058 X_{3}-0.062 X_{4}$

$X_{1}$ : The ratio of accumulated profit to the total assets

$X_{2}$ : The ratio of liabilities and the equity in the current year to the liabilities and equity of previous years

$X_{3}$ : The ratio of interest expense to the average of the sum of loans and liabilities

$X_{4}$ : The ratio of the average sum of payables accounts and documents by 12 to the sale

$Z_{i, t}$ : Bankruptcy index; if the index's value is less than 0.38 , the corporate is bankrupt, and otherwise, it is non-bankrupt.

\section{Research Findings}

The descriptive statistics of the quantitative variables are presented in Table 1 , and the results of the grouping investigation of the dummy variables are presented in Table 2. 
Table 1

Investigating the Descriptive Statistics of the Research Variables

\begin{tabular}{lrrrrrrr}
\hline Description & $\boldsymbol{M K T B K}_{\boldsymbol{i}, \boldsymbol{t}}$ & $\boldsymbol{A G \boldsymbol { E } _ { \boldsymbol { i } , \boldsymbol { t } }}$ & $\boldsymbol{R O A}_{\boldsymbol{i}, \boldsymbol{t}}$ & $\boldsymbol{L E V}_{\boldsymbol{i}, \boldsymbol{t}}$ & $\boldsymbol{S I Z}_{\boldsymbol{i}, \boldsymbol{t}}$ & $\boldsymbol{A C C}_{\boldsymbol{i}, \boldsymbol{t}}$ & $\boldsymbol{O C F}_{\boldsymbol{i}, \boldsymbol{t}}$ \\
\hline Mean & 1.936 & 3.591 & 0.150 & 0.624 & 27.640 & -0.096 & 0.127 \\
Middle & 2.053 & 3.714 & 0.097 & 0.620 & 27.473 & -0.069 & 0.108 \\
Std. dev. & 10.462 & 0.386 & 1.241 & 0.234 & 1.484 & 0.104 & 0.139 \\
Skewness & -8.977 & -0.788 & 33.674 & 1.510 & 0.767 & -3.121 & 0.646 \\
Kurtosis & 184.00 & 2.952 & 1149.777 & 10.531 & 4.119 & 19.091 & 5.263 \\
Obs. No. & 1182 & 1182 & 1182 & 1182 & 1182 & 1182 & 1182 \\
\hline
\end{tabular}

Source: Research Findings.

Table 2

Investigating the Grouping of the Dummy Variables

\begin{tabular}{|c|c|c|c|c|}
\hline \multirow[b]{2}{*}{ Observations } & \multicolumn{2}{|c|}{$A U D_{i, t}$} & \multicolumn{2}{|c|}{$B A N K R U P T_{i, t}$} \\
\hline & Percent & Numbers & Percent & Numbers \\
\hline$\overline{\text { Zero }}$ & 78.34 & 926 & 83.16 & 983 \\
\hline One & 21.66 & 256 & 16.84 & 199 \\
\hline Total observations & 100.00 & 1182 & 100.00 & 1182 \\
\hline
\end{tabular}

The dependent variable of the research is the quality of the accruals. The results showed that the accruals quality of the observations was averagely 0.962 , and the middle was -0.0688 . Since these results were so unusual, we will explain them in the last part. Regardless of the negative sign, larger values represent more profit management through the optional accruals, and its negative sign represents the inverse concept of the accruals. The research's independent variable is bankruptcy; grouping the bankruptcy variable is presented in Table 2.

Approximately $16.84 \%$ of the observed observations (199 corporate-year observations) are related to bankruptcy; On the other hand, about $83.16 \%$ of the observed observation (983 corporate-year observations) are not included in the status of bankruptcy and are considered to be non-bankrupt. The research control variables include size, leverage, asset yield, life, auditing quality, market value to book value, and the operating cash flow. The size of observed observations is averagely about 27.64 units of the natural logarithm, and its middle is about 27.47 units of the natural logarithm. The higher the value, the larger the corporate is. It is argued that in large corporates, the volume of assets used is higher. The share of liabilities in the financing the assets in the observed observations is averagely $62.43 \%$, and its middle is about $61.97 \%$. It suggests that the corporates are more likely to use liabilities in the financing, and fewer shares of corporate financing are provided through 
the equity. Profitability in the observed observations is, on average, about $15.03 \%$ of the assets used, and its middle is about $9.74 \%$. The evidence suggests that in all cases where the corporates have profitability, this value is positive, and in cases where the corporates suffer from losses, this value is negative.

The observed observation life averaged about 3.59 units of the natural logarithm, and its middle is about 3.71 units of the natural logarithm. The larger the number is, the older the corporate is, in terms of the activity experience, and some number shows the younger corporates. The listed corporates' stock market value is averagely 1.936 times the total book value of the equity; Also, the middle of market value to the book value is about 2.053 times. The observed observation's operating cash flow is averagely $12.71 \%$ of assets, and its center is about $10.77 \%$.

The positive value of this variable is the presence of a cash surplus through operational activities. If this variable is negative, the corporate faces a cash deficit through the operational activities. The method of grouping the auditing quality variable is presented in Table 2 . The results showed that the auditing organization audited $21.66 \%$ of the observations (256 corporate-year observations), and the other auditing institutions audited $78.34 \%$ of the observations (926 corporate-year observations).

According to the results, the quality of accruals, life, and the ratio of market value to book value have negative skewness, in which case their remote data is distributed to the left; but the size, leverage, return on assets, and operating cash flow have positive skewness, and the remote data is distributed to the right. The research variables have positive stretch marks, and the height of the distribution chart is longer than the normal distribution. The results of the normality of the research variables by the Jarque-Bera test are presented in Table 3. Evidence suggests that the probability values of the test statistics for all the research variables are less than the error level of 5\%. Accordingly, the variables do not have a normal distribution. Although the distribution of variables in the form of symmetric bells is not normally distributed, according to the central limit theorem in the statistics and a large number of observations, the non-normality of the variables does not create a problem. 
Table 3

Investigating the Normality of the Research Variables

\begin{tabular}{lrrrrrrr}
\hline Description & $\boldsymbol{O C F}_{\boldsymbol{i}, \boldsymbol{t}}$ & $\boldsymbol{M K T ~ B K}_{\boldsymbol{i}, \boldsymbol{t}}$ & $\boldsymbol{A G E}_{\boldsymbol{i}, \boldsymbol{t}}$ & $\boldsymbol{R O A}_{\boldsymbol{i}, \boldsymbol{t}}$ & $\boldsymbol{L E V}_{\boldsymbol{i}, \boldsymbol{t}}$ & $\boldsymbol{S I Z E}_{\boldsymbol{i}, \boldsymbol{t}}$ & $\boldsymbol{A C C Q}_{i, \boldsymbol{t}}$ \\
\hline Jarque-Bera Stat. & 334.8 & 1647200 & 122.5 & 64991990 & 3242.37 & 177.6 & 14670.8 \\
Prob. & 0.000 & 0.000 & 0.000 & 0.000 & 0.000 & 0.000 & 0.000 \\
\hline
\end{tabular}

The study results on the reliability of the research variables using the Levin Lin Chu Test for unit root are presented in Table 5. Evidence showed that the test statistic values of all the research variables were greater than the critical value and the probability of the statistics was less than the error level of 5\%. Accordingly, the variables are reliable. In the table, information about the dummy variables is not provided; the reliability of these variables, which are in the form of zero and one, cannot be studied.

Table 4

Investigating the Reliability of the Research Variables

\begin{tabular}{lrrrrrrr}
\hline Description & $\boldsymbol{O C F}_{i, \boldsymbol{t}}$ & $\boldsymbol{M K T B}_{\boldsymbol{i}, \boldsymbol{t}}$ & $\boldsymbol{A G}_{\boldsymbol{i}, \boldsymbol{t}}$ & $\boldsymbol{R O A}_{\boldsymbol{i , t}}$ & $\boldsymbol{L E V}_{\boldsymbol{i}, \boldsymbol{t}}$ & $\boldsymbol{S I Z E}_{\boldsymbol{i}, \boldsymbol{t}}$ & $\boldsymbol{A C C Q}_{\boldsymbol{i}, \boldsymbol{t}}$ \\
\hline Test Stat. & -23.59 & -346.73 & -145.62 & -12.55 & -17.91 & -15.05 & -29.56 \\
Prob. & 0.000 & 0.000 & 0.000 & 0.000 & 0.000 & 0.000 & 0.000 \\
\hline
\end{tabular}

The correlation test results of the research variables using the correlation coefficients are presented in Table 5. Evidence showed that the values of tstatistics in some cases are higher than the critical value, and the probability of t-statistic is less than the error level of 5\%. Accordingly, there is a significant correlation between some couples of variables. Evidence showed that the t-statistics value $(-2.8841)$ is more than the critical value. The probability of its statistics (0.0040) is less than the error level of 5\%; thus, there is a significant and negative correlation between the accruals quality and bankruptcy. Thus, with the increasing probability of bankruptcy, the quality of accruals decreases, and on the other hand, if the probability of bankruptcy decreases, the quality of accruals increases.

The results showed that, despite a significant correlation between some explanatory variables, these correlations are not severe, and no co-linear has taken place. However, to have more precise control over the coincidence of co-linear, when analyzing the regression model, the inflation factor of variance was evaluated so that the analysis of relations in the regression model would not be under the influence of this issue. 
Table 5

Investigating the Correlation of the Research Variables

\begin{tabular}{|c|c|c|c|c|c|c|c|c|c|}
\hline $\begin{array}{l}\text { Correlation } \\
\text { T Statistics } \\
\text { Prob. }\end{array}$ & $\begin{array}{l}\overrightarrow{2} \\
\stackrel{2}{2} \\
\stackrel{2}{*}\end{array}$ & 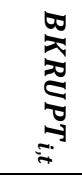 & 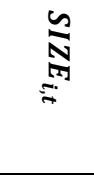 & $\stackrel{5}{=}$ & $\begin{array}{l}\overrightarrow{0} \\
0 \\
=\end{array}$ & ते & $\underset{\approx}{\mathbb{S}}$ & 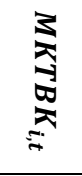 & $\stackrel{2}{2}$ \\
\hline$\overline{A C Q U A L}_{i, t}$ & $\begin{array}{l}1.00 \\
---- \\
----\end{array}$ & & & & & & & & \\
\hline$B K R U P T_{i, t}$ & $\begin{array}{r}-\mathbf{0 . 0 8} \\
-2.88 \\
0.00\end{array}$ & $\begin{array}{l}1.00 \\
---- \\
---\end{array}$ & & & & & & & \\
\hline$S I Z E_{i, t}$ & $\begin{array}{l}\mathbf{0 . 0 4} \\
1.49 \\
0.14\end{array}$ & $\begin{array}{l}\mathbf{0 . 0 5} \\
1.72 \\
0.09\end{array}$ & $\begin{array}{l}1.00 \\
---- \\
----\end{array}$ & & & & & & \\
\hline$L E V_{i, t}$ & $\begin{array}{r}\mathbf{- 0 . 1 1} \\
-3.69 \\
0.00\end{array}$ & $\begin{array}{l}\mathbf{0 . 1 0} \\
3.41 \\
0.00\end{array}$ & $\begin{array}{l}\mathbf{0 . 0 3} \\
1.00 \\
0.32\end{array}$ & $\begin{array}{c}1.00 \\
---- \\
----\end{array}$ & & & & & \\
\hline$R O A_{i, t}$ & $\begin{array}{l}\mathbf{0 . 0 1} \\
0.38 \\
0.70\end{array}$ & $\begin{array}{r}-\mathbf{- 0 . 0 3} \\
-1.00 \\
0.32\end{array}$ & $\begin{array}{r}-\mathbf{0 . 0 3} \\
-1.20 \\
0.23\end{array}$ & $\begin{array}{r}-\mathbf{0 . 0 4} \\
-1.23 \\
0.22\end{array}$ & $\begin{array}{c}1.00 \\
--- \\
----\end{array}$ & & & & \\
\hline$A G E_{i, t}$ & $\begin{array}{l}\mathbf{0 . 0 1} \\
0.18 \\
0.85\end{array}$ & $\begin{array}{l}\mathbf{0 . 0 6} \\
2.03 \\
0.04\end{array}$ & $\begin{array}{l}\mathbf{0 . 0 0} \\
0.02 \\
0.99\end{array}$ & $\begin{array}{l}\mathbf{0 . 0 3} \\
1.00 \\
0.32\end{array}$ & $\begin{array}{l}\mathbf{0 . 0 0} \\
0.12 \\
0.90\end{array}$ & $\begin{array}{c}1.00 \\
---- \\
----\end{array}$ & & & \\
\hline$A U D_{i, t}$ & $\begin{array}{l}\mathbf{0 . 0 2} \\
0.78 \\
0.44\end{array}$ & $\begin{array}{l}\mathbf{0 . 0 5} \\
1.68 \\
0.09\end{array}$ & $\begin{array}{r}\mathbf{0 . 2 9} \\
10.28 \\
0.00\end{array}$ & $\begin{array}{l}\mathbf{0 . 1 0} \\
3.54 \\
0.00\end{array}$ & $\begin{array}{r}\mathbf{- 0 . 0 1} \\
-0.49 \\
0.63\end{array}$ & $\begin{array}{l}\mathbf{0 . 0 6} \\
1.91 \\
0.06\end{array}$ & $\begin{array}{l}1.00 \\
---- \\
----\end{array}$ & & \\
\hline$M K T B K_{i, t}$ & $\begin{array}{l}\mathbf{0 . 0 5} \\
1.79 \\
0.07\end{array}$ & $\begin{array}{l}\mathbf{0 . 0 1} \\
0.35 \\
0.73\end{array}$ & $\begin{array}{l}\mathbf{0 . 0 3} \\
1.20 \\
0.23\end{array}$ & $\begin{array}{r}-\mathbf{0 . 1 2} \\
-4.10 \\
0.00\end{array}$ & $\begin{array}{l}\mathbf{0 . 0 3} \\
1.00 \\
0.32\end{array}$ & $\begin{array}{l}\mathbf{0 . 0 0} \\
0.14 \\
0.89\end{array}$ & $\begin{array}{l}\mathbf{0 . 0 7} \\
2.26 \\
0.02\end{array}$ & $\begin{array}{l}1.00 \\
---- \\
----\end{array}$ & \\
\hline$O C F_{i, t}$ & $\begin{array}{r}-\mathbf{0 . 5 1} \\
-20.40 \\
0.00\end{array}$ & $\begin{array}{r}\mathbf{- 0 . 1 6} \\
-5.49 \\
0.00\end{array}$ & $\begin{array}{l}\mathbf{0 . 0 6} \\
2.06 \\
0.04\end{array}$ & $\begin{array}{r}-\mathbf{0 . 2 7} \\
-9.66 \\
0.00\end{array}$ & $\begin{array}{l}\mathbf{0 . 0 6} \\
2.16 \\
0.03\end{array}$ & $\begin{array}{r}-\mathbf{0 . 0 9} \\
-3.24 \\
0.00\end{array}$ & $\begin{array}{l}\mathbf{0 . 0 2} \\
0.79 \\
0.43\end{array}$ & $\begin{array}{l}\mathbf{0 . 0 4} \\
1.20 \\
0.23\end{array}$ & $\begin{array}{c}1.00 \\
---- \\
----\end{array}$ \\
\hline
\end{tabular}

To evaluate the subject of the research, a certain hypothesis has been developed, and a regression model has been used to examine the subject. Since the data related to the different corporates in different years should be used in the form of corporate-year observations to test the research hypothesis, it is necessary to first identify the appropriate regression model and do the tests to determine the type of data and type of effects. The results of these tests are presented in Table 6 . 
Table 6

Investigating the Pattern Selection of Regression Model for the Relationship between the Quality of Accruals and Bankruptcy

\begin{tabular}{|c|c|c|c|c|c|}
\hline \multicolumn{6}{|c|}{$\begin{array}{c}\operatorname{ACCRUAL}_{i, t}=\alpha+\beta_{1} \text { BANKRUPT }_{i, t}+\beta_{2} \operatorname{SIZE}_{i, t}+\beta_{3} L E V_{i, t}+\beta_{4} R O A_{i, t}+\beta_{5} A G E_{i, t} \\
+\beta_{6} A U D_{i, t}+\beta_{7} M K T B K_{i, t}+\beta_{8} O C F_{i, t}+\varepsilon_{i, t}\end{array}$} \\
\hline Test & Probability & $\begin{array}{l}\text { Freedom } \\
\text { degree }\end{array}$ & Value & Statistics & Result \\
\hline Chow & 0.0000 & $(196,977)$ & 2.587292 & F-Limer & $\begin{array}{l}\text { panel } \\
\text { combined } \\
\text { data }\end{array}$ \\
\hline Hausman & 0.0000 & 8 & 507.109177 & Chi 2 & $\begin{array}{l}\text { Fixed } \\
\text { effects } \\
\text { method }\end{array}$ \\
\hline
\end{tabular}

According to the results of the Chow test and based on the model of FLimer statistics (2.5872), which is more than the critical value and its probability $(0,0000)$, which is less than the error level of $5 \%$, the combined data method has been preferred than the integration data method. According to the Hausman test results and based on the Chi-square (507.10), which is more than the critical value with probability $(0,0000)$, which is less than the error level of 5\%, the use of the fixed effects method has been preferred to the random effects. The final results of the research model test using the combined data method and the fixed effects are presented in Table 7. 
Table 7

Final Analysis of the Relationship between the Quality of Accruals and Bankruptcy

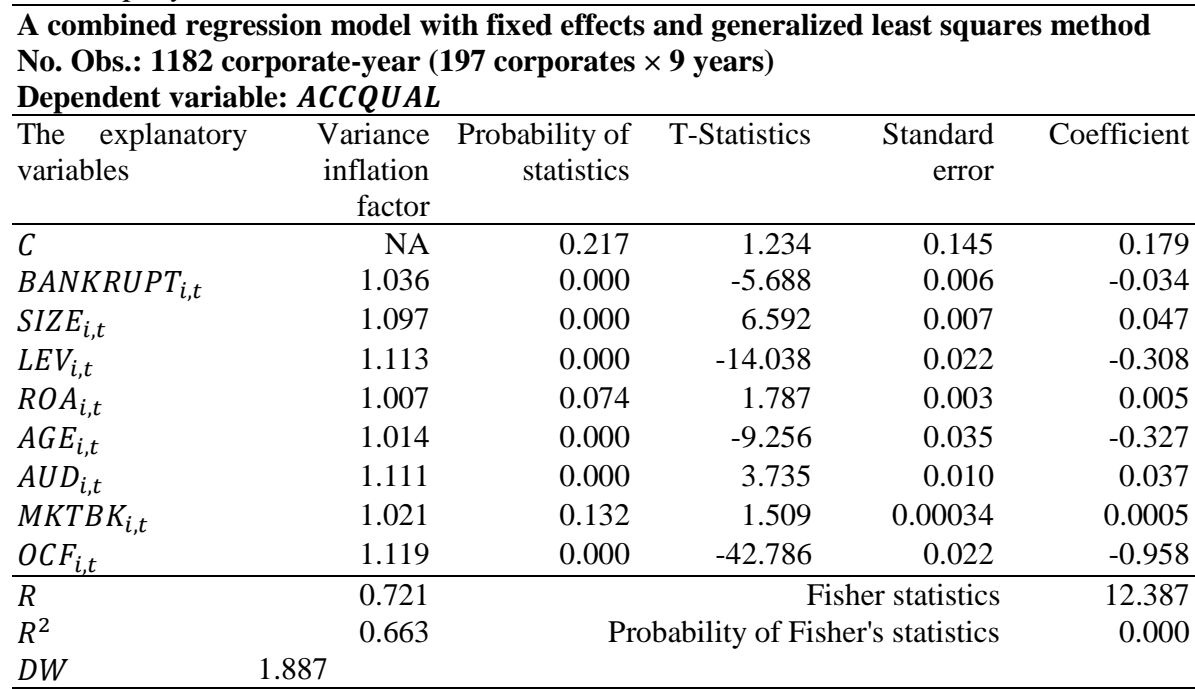

Considering that the Fisher statistic (12.387) is more than the critical value and its probability (0.000) is less than the error level of 5\%, the model under study, in general, is significant in terms of the linear relations. (i.e. it is expected that there is a significant relationship between the dependent variable and at least one of the model's explanatory variables). The Durbin-Watson statistics (1.8869) is nearly 2 and in the range of 1.5 to 2.5 . It means that there is no compliance problem between the remains of the model and the condition for the remains' independence. Since the inflation factor of the variance of all variables in the model is numerically less than 5, there is no co-linear between the explanatory variables of the model, and this justifies the simultaneous placement of variables in the model under study; as a result, it is possible to cite the obtained relations. The coefficient of determination (0.72111) and the adjusted coefficient of determination (0.6692) indicated that the model's independent and control explanatory variables could explain the extent of the variation of the model's dependent variable. In this way, the variables applied to the right of the regression equation are somewhat selected appropriately.

Considering that the percentage of t-statistics of the bankruptcy probability $(-5.6875)$ is higher than the critical value and also its probability of t-statistics $(0.0000)$ is less than the error level of $5 \%$, it can be said that there is a 
significant relationship between the quality of accruals and bankruptcy of corporates and according to this result, the research hypothesis is confirmed. To be aware of the relationship between these two variables, it is necessary to note the sign of coefficients. As the coefficient of bankruptcy effect (-0.0341) is somewhat negative, it can be concluded that there is a significant and inverse relationship between the quality of accruals and the bankruptcy of the corporates. It means that by increasing (decreasing), the probability of bankruptcy, accruals' quality is reduced (increased). When the bad financial situation threatens corporates' continuity, the executives try to hide these unfavorable conditions from the viewpoint of users of financial information using profit management through the optional accruals. In such circumstances, the use of profit management through the optional accruals reduces the quality of accruals. While in non-bankrupt corporates that are financially in a more favorable position, accruals for profit management are reduced, and the accruals quality is higher.

The other results indicate that the variables such as size, leverage, return on assets, life, auditing quality, operational cash flow have a significant relationship with the quality of accruals. This relationship is significant and positive in terms of size, return on assets, and auditing quality, which indicates the direct relationship between these variables and the quality of accruals. Thus, in bigger size corporates in terms of size, more profitability from the return on assets, larger percentage of the auditor's presence as an index of the quality of auditing, the quality of accruals is more in a direct direction. In smaller corporates in terms of size, less profitability from the return on assets, the lower percentage for a large auditor's presence as an index of the quality of auditing, the quality of accruals is lower in a direct direction. In the other variables, the results are different; in the case of leverage, life, and operating cash flow, there is a significant and negative relationship. In the corporates with less financial leverage in terms of liability ratio, lower life expectancy in terms of working time experience, and lower cash flow from operational activities, the accruals' quality is greater in the opposite direction. The corporates with more financial leverage in terms of liability ratio, longer life in terms of working time experience, and more cash flow from operating activities have a lower quality of accruals in the opposite direction. Meanwhile, the relationship between the market value to the book value and the accruals quality was not statistically significant.

To further research the study's subject, the research observations were classified into two distinct groups: non-bankrupt and bankrupt according to the status of bankruptcy, and the status of research variables was investigated 
in the separate groups through the test of mean comparison. The results of this test are presented in Table 8. It shows that there is a significant difference between the mean values of the bankruptcy index of Shirata's model in two bankrupt and non-bankrupt groups according to t-statistics (39.338), which is more than the critical value and its probability $(0.0000)$, which is less than the error level 5\%. Thus, the mean bankruptcy index of the Shirata model in the bankrupt observations group is less than the mean bankruptcy index of the Shirata model in the non-bankrupt observations group. There is a significant difference between the mean values of accruals quality of two bankrupt and non-bankrupt observations groups according to t-statistics (6.6931), which is more than the critical value with probability $(0.20000)$, which is less than the error level of 5\%. It suggests that bankrupt and non-bankrupt observations are different in terms of the quality of accruals.

The surveys show that the observations that were likely to be bankrupt compared to those that were not bankrupt have a typically larger size, greater leverage, lower returns, longer life, a bigger percentage of auditor's presence, higher market value to higher book value, and lower operating cash flow. Evidence from the comparative tests shows that there is a significant difference between the mean value of financial leverage, return on assets, life expectancy, and operating cash flow in both bankrupt and non-bankrupt observations groups (t-statistics -3.4079, 2.1719-2.0277 and 5.4867, which are greater than the critical values with probabilities $0,0007,0.0301,0.0428$, 0,0000 which are less than error level 5\%). In contrast, there is not a significant difference between the mean value of size, audit quality, and market value to book value ratio in bankrupt and non-bankrupt observations groups (t-statistics $-1.7191,-1.6801$, and -0.3504 , which are less than the critical values with probabilities $0,585,0.0932$, and 0.7260 which are greater than the error level 5\%). 
Table 8

Comparative Survey of the Research Variables By Divided Into the Bankrupt and Non-Bankrupt Observations

\begin{tabular}{|c|c|c|c|c|c|}
\hline \multirow{2}{*}{ variables } & \multicolumn{2}{|c|}{$\begin{array}{r}\text { comparison of the means } \\
\text { test }\end{array}$} & \multicolumn{3}{|c|}{ Mean values of variables } \\
\hline & Prob. & t-statistics & $\begin{array}{r}\text { Total } \\
(1883 \text { obs. })\end{array}$ & $\begin{array}{r}\text { broken } \\
(199 \text { obs. })\end{array}$ & $\begin{array}{r}\text { Non-broken } \\
(983 \text { obs. }) \\
\end{array}$ \\
\hline$\overline{A C C Q U A L_{i, t}}$ & 0.000 & 6.693 & -0.096 & -0.100 & -0.026360 \\
\hline$Z_{i, t}$ & 0.000 & 39.383 & 0.530 & 0.211 & 0.594337 \\
\hline$S I Z E_{i, t}$ & 0.086 & -1.719 & 27.640 & 27.805 & 27.60677 \\
\hline$L E V_{i, t}$ & 0.0007 & -3.408 & 0.624 & 0.676 & 0.614004 \\
\hline$R O A_{i, t}$ & 0.030 & 2.172 & 0.150 & 0.070 & 0.166560 \\
\hline$A G E_{i, t}$ & 0.043 & -2.028 & 3.591 & 3.642 & 3.581168 \\
\hline$A U D_{i, t}$ & 0.093 & -1.680 & 0.217 & 0.2613 & 0.207528 \\
\hline$M K T B K_{i, t}$ & 0.726 & -0.350 & 1.936 & 2.173 & 1.888075 \\
\hline$O C F_{i, t}$ & 0.000 & 5.487 & 0.127 & 0.078 & 0.136950 \\
\hline
\end{tabular}

\section{Discussion and Conclusion}

This study's main topic is to investigate the relationship between accruals quality and the bankruptcy of corporates. Rapid technological progress and extensive environmental changes have accelerated the acceleration of the economy, and the increasing competition of the corporates has limited profit and increased the probability of financial distress and bankruptcy of the corporates.

Earlier studies have shown that helpless corporates' executives manipulate the financial information and even their actual activities to hide or postpone the financial turmoil. Some empirical evidence has shown that profit reporting is affected by the crisis, financial distress, and corporates' bankruptcy. Many studies have concluded that the corporates' bankruptcy and financial distress have led the corporate executives to manage the profit more. Since the profit management and quality of accruals decrease with increasing profit management, accruals' quality is expected to fall in corporate bankruptcy. Evidence from the researches suggests that the quality of profits of bankrupt corporates is less due to opportunistic profit management than the nonbankrupt corporates (Rosner, 2003; Li, Abeysekera \& Ma, 2011).

Jaggi \& Picheng (2002) found that bankrupt corporates' executives manage the profits by choosing the optional accruals increasing the profit. Ming Chia, Lapsley, Lee (2007) found that the large auditing corporates, especially in times of financial crisis, lead to a reduction in profit management through the auditing with quality. Rosner (2003) showed that the bankrupt corporates had 
manipulated the profits upside-down over the years before the bankruptcy when their continuity of activity was doubted. Charitou, Lambertides \& Trigeorgis (2007) found that the bankrupt corporates had the profit management the year before bankruptcy. They showed that the executives in the corporates with high bankruptcy probability move their downward income. Garcia Lara, Garcia Osma \& Neophytou (2009) found that the bankrupt corporates increasingly managed their profits four years before the bankruptcy. Li, Abeysekera \& Ma (2011) showed that bankrupt corporates prefer optimistic profit management. Charitou, Lambertides \& Trigeorgis (2011) showed that the helpless corporates manage the profits for their purposes more than the sound corporates. Habib, Bhuiyan \& Islam (2013) found that executives in helpless corporates are more involved in profit management than sound corporate executives. Campa \& Camach (2013) found that bankrupt corporates tend to make profit management compared to non-bankrupt corporations. Li, Abeysekera \& Ma (2014) found that sound corporates' accruals are significantly higher in quality than the non-bankrupt corporates. Nagar \& Sen (2016) found that corporates move into the accruals incremental management with the increasing the financial distress situation.

Ahmadpour and Shahsavari (2014) showed that the corporates subject to the Altman bankruptcy model's thresholds had increased profit management. Kurdistani and Tatali (2014) showed that the bankrupt corporates have the lowest profit quality and the sound corporates have the highest level of profit quality. The bankrupt corporates have manipulated the profits more than the sound corporates. Bazrafshan \& Arefmanesh (2015) found that the bankrupt corporates managed to profit in the year before the bankruptcy. Salehi and Bazarger (2015) found that the relationship between the optional accruals and the adjusted optional accruals as an index of the profit management is significant and direct with the bankruptcy based on Altman's model.

It is while the other researches have provided different pieces of evidence. Smith, Kastel \& Robinson (2001) showed that the bankrupt corporates did not change the accruals for infusion of the profit in the year before bankruptcy. Dimitras et al. (2015) showed that financially distressed corporates audited by large auditors had fewer optional accruals. Jahantigh (2013) showed a significant difference between the profit management in the corporates during the financial crisis. Lenard et al. (2016) found that there was a significant and positive relationship between the reporting of weaknesses in internal controls and the manipulation of profits through real activities. The results showed that when corporates report weaknesses in internal controls, they manage profits more through their actual activities and do not use optional accruals as an 
alternative to manage the profit through real activities. Accordingly, the results of this research are contrary to the findings of the above researches.

According to the results, it was observed that the increase (decrease) in the probability of bankruptcy in the corporates would decrease (increase) the quality of accruals. Evidence also suggests that the size, leverage, return on assets, life, auditing quality, and operational cash flow have a significant relationship to accruals' quality. Accordingly, the different groups of shareholders, creditors, stock organizations, auditors, financial analysts, and so on are suggested to consider the role of factors influencing the quality of accruals. The awareness of these and understanding how these factors can impact; can be a useful guide for assessing corporate profit management through the accruals to make the right decisions for the different groups. The investors, analysts, and the other users of financial information are advised to pay more attention to the quality of information published, in particular, the profit, and not merely refer to the reported profit figures and also takes into account the quality of accruals and the quality of profit in their decisions. Specifically, it is necessary for different groups that use financial information to accurately assess the quality of financial information, particularly the profit and the accruals, when facing financial distress and bankruptcy. Also, for the Shirata model, we can find some variables such as Retained Earnings to Total Liabilities and Owners' Equity, Net Income before Tax to Total Liabilities and Owners' Equity, Inventory Turnover Period, and Interest Expenses to Sales.

The evidence provided in this study can be useful for lawmakers who develop and implement corporate governance rules to prevent opportunistic behavior. To improve the quality of information, it is recommended that standard-setting entities create the financial reporting requirements to restrict management using the accepted accounting principles and increase the quality of accounting information. These results can help the accountants better understand how the executives use accounting standards' inherent option to hide the crisis-stricken corporates' weak performance in bankruptcy situations. These results can also be useful for the other groups, including analysts, creditors, and researchers who use the accounting figures to assess the corporate probability of bankruptcy. It is suggested to the executives of corporates to make desirable and quality financial reports to reduce the information asymmetry and solve the problems of representation. Obviously, in the face of such corporates, the auditors do their own risk analyzes with fewer risks and can provide reasonable feedback to the users who rely on the audit reports for making a decision. 
Investigators are suggested to investigate the following issues in future researches:

- Implementing the research using the other financial reporting quality criteria and comparative evaluation

- Implementing the research using the other bankruptcy models and comparative evaluation

- Investigating the effect of corporate governance on the relationship between the quality of accrual and bankruptcy

- Investigating the impact of the corporate life cycle on the relationship between the quality of the accruals and bankruptcy

- Investigating the effect of representation costs on the relationship between the quality of accruals and bankruptcy.

- Investigating the effect of information asymmetry on the relationship between accrual quality and bankruptcy.

- Investigating the effect the financial development during a recession on the relationship between the quality of accruals and bankruptcy

\section{References}

Ahmadpoor A. Shahsavari M. (2014), Earnings Management and the Effect of Earnings Quality on Future Profitability of the Tehran Stock Exchange Bankrupt Firms. Empirical Studies in Financial Accounting Quarterly, 11, (41), 37-58.

Alaminos, D., del Castillo, A., \& Fernández, M. Á. (2016). A Global Model for Bankruptcy Prediction. PLOS ONE, 11(11), e0166693.

Al-Attar, A., Hussain, S., \& Zuo, L. Y. (2008). Earnings quality, bankruptcy risk, and future cash flows. Accounting and Business Research, 38(1), 5-20.

Aldahray, A., \& Alnori, F. (2020). Impact of regulatory environment on accruals manipulation of bankrupt firms. Spanish Journal of Finance and Accounting / Revista Española de Financiación y Contabilidad, 50(1), 1-29.

Alexopoulos, E. C. (2010). Introduction to multivariate regression analysis. Hippokratia, 14(Suppl 1), 23.

Bazrafshan A., \& Arefmanesh Z. (2015), Earnings behavior in bankrupt firms: the role of auditor, Journal of Asset Management and Financing, 2(4), 1-14.

Biddle, G. C., Ma, M. L. Z., \& Song, F. M. (2020). Accounting Conservatism and Bankruptcy Risk. Journal of Accounting, Auditing \& Finance, 0148558 X2093424.

Campa, D., \& Camacho-Miñano, M. D. M. (2014). Earnings management among bankrupt non-listed firms: evidence from Spain. Spanish Journal of Finance and Accounting/Revista Espanola de Financiacion y Contabilidad, 43(1), 3-20. 
Charitou, A., Lambertides, N., \& Trigeorgis, L. (2007). Earnings behaviour of financially distressed firms: the role of institutional ownership. Abacus, 43(3), 271-296.

Charitou, A., Lambertides, N., \& Trigeorgis, L. (2011). Distress risk, growth and earnings quality. Abacus, 47(2), 158-181.

Chriss, N., \& Ginzburg, V. (2010). Representation Theory and Complex Geometry. Birkhäuser Boston.

Dechow, P. M., Sloan, R. G., \& Sweeney, A. P. (1995). Detecting earnings management. The Accounting Review, 70(2), 193-225.

Dechow, P. M., \& Dichev, I. D. (2002). The quality of accruals and earnings: The role of accrual estimation errors. The Accounting Review, 77(s-1), 35-59.

Dimitras, A. I., Kyriakou, M. I., \& Iatridis, G. (2015). Financial crisis, GDP variation and earnings management in Europe. Research in International Business and Finance, 34, 338-354.

García Lara, J. M., Osma, B. G., \& Neophytou, E. (2009). Earnings quality in ex-post failed firms. Accounting and business research, 39(2), 119-138.

Habib, A., Uddin Bhuiyan, B., \& Islam, A. (2013). Financial distress, earnings management and market pricing of accruals during the global financial crisis. Managerial Finance, 39(2), 155-180.

Healy, P. M., \& Wahlen, J. M. (1999). A review of the earnings management literature and its implications for standard setting. Accounting Horizons, 13(4), 365-383.

Jaggi, B., \& Lee, P. (2002). Earnings management response to debt covenant violations and debt restructuring. Journal of Accounting, Auditing \& Finance, 17(4), 295-324.

Jahantigh, S. (2014). Study of earnings management in profitable companies listed on the Tehran Stock Exchange during the global financial crisis with emphasis on large and small companies. The First National Conference on the Place of Management and Accounting in the Modern World of Business, Economy and Culture. Aliabad Katul.

Jones, J. J. (1991). Earnings management during import relief investigations. Journal of Accounting Research, 29(2), 193-228.

Jouzbarkand, M., Keivani, F. S., Khodadadi, M., Fahim, S. R. S. N., \& Aghajani, V. (2013). Bankruptcy prediction model by Ohlson and Shirata models in Tehran Stock Exchange. World Applied Sciences Journal, 21(2), 152-156.

Lenard, M. J., Petruska, K. A., Alam, P., \& Yu, B. (2016). Internal control weaknesses and evidence of real activities manipulation. Advances in accounting, 33, 47-58.

Li, F., Abeysekera, I., \& Ma, S. (2011). Earnings management and the effect of earnings quality in relation to stress level and bankruptcy level of Chinese listed firms. Corporate Ownership and Control, 9(1), 366-391.

Li, F., Abeysekera, I., \& Ma, S. (2014). The effect of financial status on earnings quality of Chinese-listed firms. Journal of Asia-Pacific Business, 15(1), 4-26. 
Ming Chia, Y., Lapsley, I., \& Lee, H. (2007). Choice of auditors and earnings management during the Asian financial crisis. Managerial Auditing Journal, 22(2), 177-196.

Nagar, N., \& Sen, K. (2016), Earnings Management Strategies during Financial Distress", IIMA Working Papers WP2016-02-03, Indian Institute of Management Ahmedabad, Research and Publication Department.

Rosner, R. L. (2003). Earnings manipulation in failing firms. Contemporary Accounting Research, 20(2), 361-408.

Salehi, M., Bazrgar, H. (2015). The Relationship between Earnings Quality and Insolvency Risk. Financial Management Strategy, 3(1), 113-140.

Semba, H. D., \& Kato, R. (2019). Does Big N matter for audit quality? Evidence from Japan. Asian Review of Accounting, 27(1), 2-28.

Shirata, C. (1995). Read the sign of business failure. Journal of Risk and Management, 23, 117-138.

Shirata, C. Y. (1998). Financial ratios as predictors of bankruptcy in Japan: An empirical research. In Proceedings of The Second Asian Pacific Interdisciplinary Research in Accounting Conference, 437-445.

Sloan, R. G. (1996). Do stock prices fully reflect information in accruals and cash flows about future earnings? Accounting Review, 71(3), 289-315.

Smith, M., Kestel, J.-A., \& Robinson, P. (2001). Economic Recession, Corporate Distress and Income Increasing Accounting Policy Choice. Accounting Forum, 25(4), 334-352.

Stolowy, H., \& Breton, G. (2004). Accounts Manipulation: A Literature Review and Proposed Conceptual Framework. Review of Accounting and Finance, 3(1), 592.

Vichitsarawong, T., Eng, L. L., \& Meek, G. K. (2010). The impact of the Asian financial crisis on conservatism and timeliness of earnings: Evidence from Hong Kong, Malaysia, Singapore, and Thailand. Journal of International Financial Management \& Accounting, 21(1), 32-61. 